\title{
Identification of Housing Crisis in a Confined Settlement: A Study of Mohammadpur Geneva Camp
}

\author{
Masud Ur Rashid \\ Department of Architecture, Southeast University, Dhaka-1208, Bangladesh \\ *Email: masudurrashid@yahoo.com
}

ARTICLE INFORMATION

Received: July 16, 2019

Revised: September 10, 2019

Accepted: October 01, 2019

Published online: January 27, 2020

\section{Keywords:}

Confined settlement, Geneva camp,

housing problems, low-income

settlement, stateless people

\begin{abstract}
Urdu speaking people living in Geneva camp of Dhaka have become a marginally displaced community since 1971 . Geneva camp is overcrowded as they have no chance of living outside of the camps because of their statelessness. The camp is a denselypopulated settlement and have its own natural physical growth in terms of social and economic transformation day by day. This brings a lot of physical, socio-cultural and economic problems. This study illustrates the housing problems in different domains in the Geneva camp with their attributes. Lack of spaces and other facilities in a low-income settlement have their impact on the way of overall livelihood of the inhabitants. The physical characteristics and other major factors that affect the physical environment of settlement are discussed in this paper.
\end{abstract}

\section{Introduction}

In Bangladesh, the number of increasing urban poor is alarming. Slum census preliminary report 2014 from BBS reveals that the number of slum dweller increased four times in 17 years (Islam et al., 2016; Rashid, 2019). Government has failed to provide them with liveable housing condition due to improper housing policy. Scattered attempts to house the poor has mostly been unsuccessful and no remarkable achievement has been seen. It is high time to come up with a multidisciplinary action to address low income housing issue (Mowla et al., 2008).

Housing is defined as the complete residential environment or micro district including the physical structure, all necessary services, facilities and apparatus for the total health and social well-being of the individual and family (Abrams, 1964). It is seen as the physical environment in which the family and society's basic units develop and sustain. Housing structures are enclosures in which people are housed for lodging, living accommodation or even work places. According to Abrams (1964, p. 13), "housing is not only a shelter but also part of the fabric of the neighbourhood life and of the whole social milieu". It touches upon many facets of economic activity and development. Thus housing provides social contacts, good image, a sense of belonging and an indicator of social status. Economically, housing represents a major portion of the family budget or that of an establishment, yet in the realm of private and public investment, the built environment represents a man's most tangible material asset (Kinyungu, 2004).

Geneva Camp in Dhaka's Mohammadpur is a colony of the stranded Pakistanis who migrated to the then East Pakistan from the Indian state of Bihar during the partition of 1947. The Urdu-speaking Muslims have been living there since the end of the 1971 War of Liberation. The camp, is a densely-populated settlement of more than thirty thousand Biharis where each family with eight to ten members on average lives in one room, and around 90 people share a latrine (The 
Daily Star, 2018). Bihari people are more excluded than the mainstream Bengali community in many respects. They have limited access to health services, educational facilities, labor-market and social services. (Bhattacharjee, 2018; Refugees International, 2006)

In 1947 during the partition of Indian subcontinent, a large number of Urdu speaking Muslims migrated to East Pakistan (then) or Bangladesh mostly from the state of Bihar and from other states likeUttar Pradesh, Odisha \& West Bengal. Almost 1.3 million Urdu speaking Muslims came to this region. (Wikipedia, 2019; Sholder, 2011)

In 1971 during the liberation war, a section of the Urdu-speaking community played an antiliberation role by siding with the West Pakistan army. Consequently, at the end of the war, they lost their homes, businesses, properties and employment (Siddiqis, 2013). They were scattered and in 1974 the International Committee of the Red Cross along with United Nations High Commissioner for Refugees (UNHCR) built settlements mostly on public land and buildings to provide shelter, food and medical support to the displaced people. (Wikipedia, 2019)

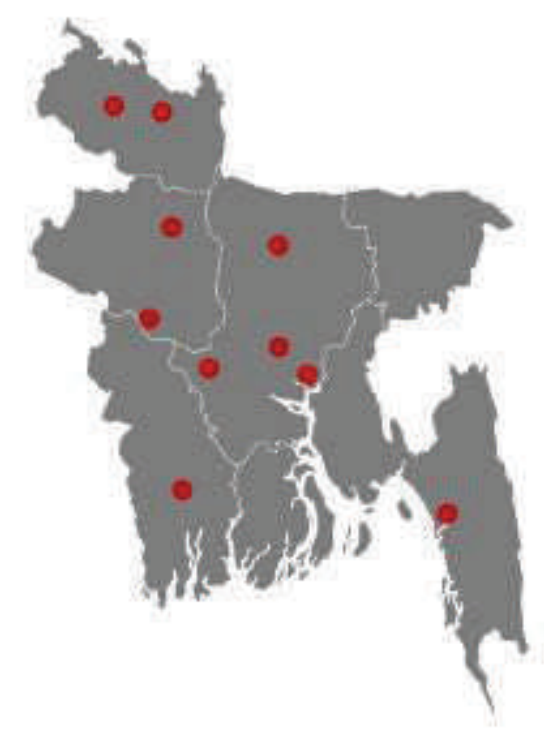

Figure 1: Location of major camp districts in Bangladesh map. (Source: Muhtasim, 2018).

\section{Background}

The Biharis are Pakistani nationals, essentially stranded in Bangladesh since 1971, when the former East Pakistan became the independent country of Bangladesh. They once lived in the Indian state of Bihar, but migrated from India in 1947 after the partition of India. At that time, more than three thousand kilometers of India separated West and East Pakistan (Haider, 2003). However, the Urdu-speaking Biharis in East Pakistan could not assimilate with the surrounding Bengali society there and remained a distinct cultural linguistic group. They generally identified with West Pakistani society and associated themselves with the West Pakistani governing elite. (VOA, 2009)

In the early 1970s, civil war broke out between East and West Pakistan, and the Biharis sided with West Pakistan. In December 1971, following a war with India, Pakistani forces surrendered to a joint command composed of Indian and Bangladeshi forces and East Pakistan became the independent state of Bangladesh. After Pakistani army and civilians were evacuated, the Biharis found themselves unwelcome in both countries. Since then, most of these Biharis have been living in refugee camps in Bangladesh, hoping to be repatriated to Pakistan. Historical Background (The state of the World's Refugees, 2000).

At least 116 (One hundred and sixteen) settlements were established throughout the country providing shelter more than 4 Lacs refugees. These Urdu-speaking displaced people had no documents to support recognition as citizens in any country thus they became refugees. (MRGI, 2019)

In 1972 the International Committee for Red Cross (ICRC) built a number of camps in Bangladesh to assist this community. There were 25 camps in Mirpur and six in Mohammadpur. The six camps in Mohammadpur are: Geneva Camp, Town Hall Camp, C R O Camp, Market Camp, Community Center Camp, Staff Quarter Camp. The head office of ICRC is in Geneva. That is why one of the camps in Mohammadpur was named Geneva Camp. The population of Geneva Camp is 30,000.

Firstly 8'X 8' or 64 sqft. plots were allocated for two refugees where they started living in tents. Later they made more durable structures and soon started increasing their living spaces by making multistoried buildings on the same 8'X8' footprint because of population growth within the camp. In each of these modules a family consisting of 5 to 8 members live. There are no amenity spaces like kitchen or living rooms. All activities from preparing food to eating and sleeping takes place in the same 8'X8' room. These 
rooms sometimes increased up to $10^{\prime}$ on the upper floors because of extending over the circulation spaces beneath. (Source: UNHCR)

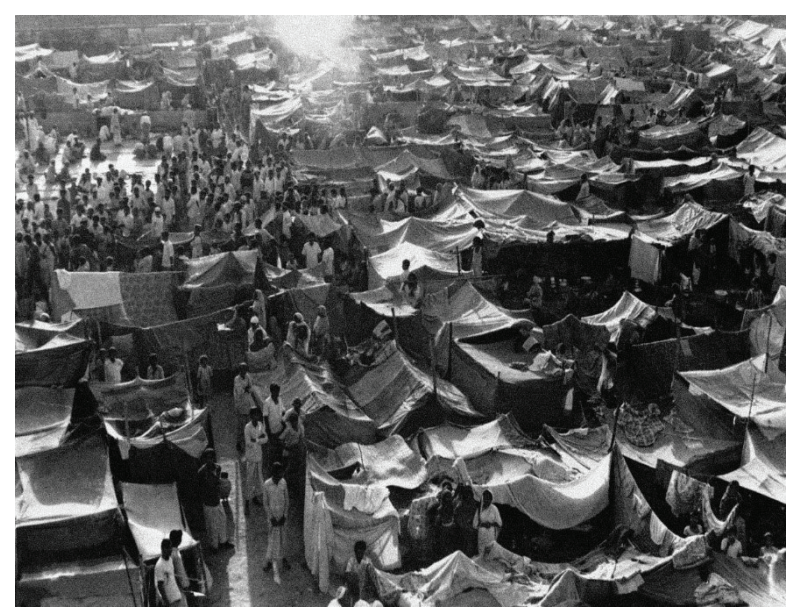

Figure 2: View of the Geneva camp on March 1972 right after the independence of Bangladesh. (Source: Internet).

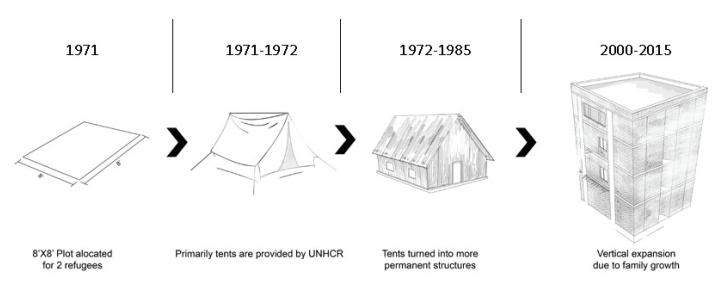

Figure 3: Chronological development of settlement unit in camp.

All the camps are overcrowded as they have no chance of living outside of the camps because of their statelessness. Geneva camp, the largest camp among the one hundred sixteen camps, is located in Dhaka with an area of 14.5 acres of land. Within this small area around thirty thousand people live in inhuman conditions.

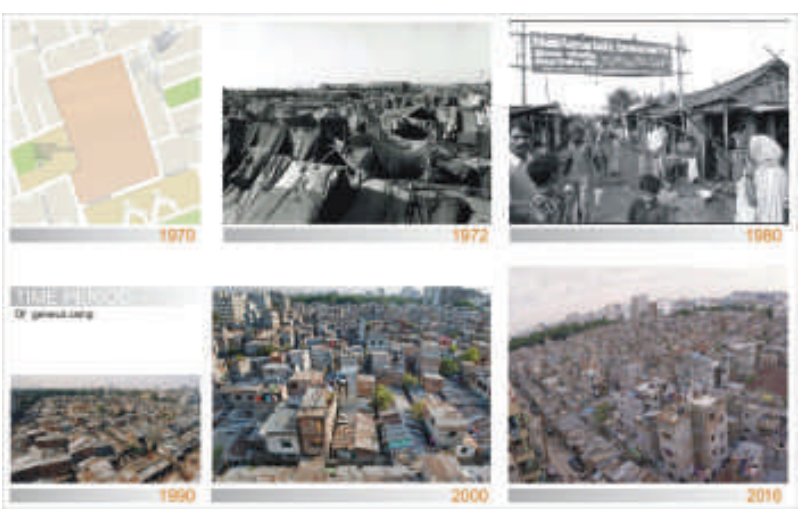

Figure 4: Geneva camp in different time period.

\section{Methodology}

This study is an outcome of an under-graduate study of sixteen students of Architecture Department of Southeast University of Dhaka, Bangladesh took place in the year 2019. The study conducted as a part of the Design Studio under the supervision and leadership of the author with the following objectives:

- To give insight into traditional ways of community living in a specific settlement by learning from real life facts and theories and concepts of architecture in housing.

- To identify the housing crisis as well as the socio-economic problems of the specific community settlement by which the students rethink housing problem and try to design it with new thoughts and views.

- To make a documentation of housing transformation to know the process of negotiation of different attributes after 48 years of their settlement.

This study is based on both primary and secondary data. Primary data has been collected through field surveys and interviews. The field survey data have been interpreted into analysis of houses with plans, photographs and description. Interviews were collected from the dwellers, development partners, local leaders and local representatives. Secondary data has been used to cross check the historical background of study area with primary data and understand and establish the context of the study. Secondary data source includes research papers and articles, dissertations, newspaper articles, government census reports. Finally, observations on their living and recommendations have been presented.

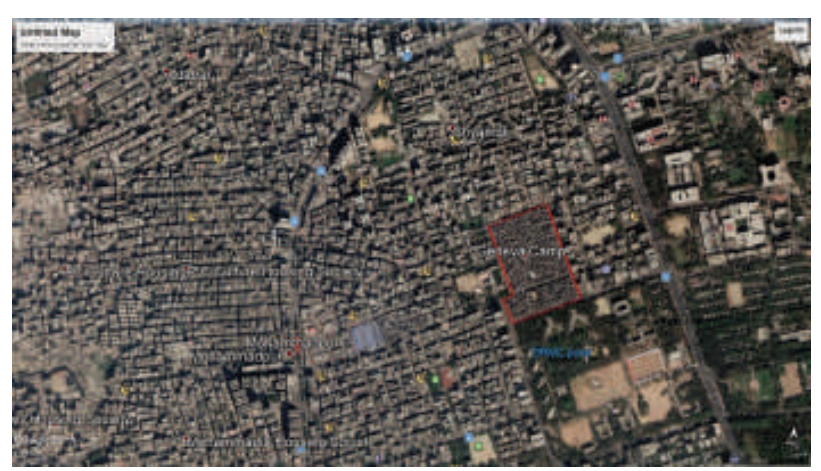

Figure 5: Satellite view from Google Earth view of Mohammadpur Geneva Camp.

The study has been designed in two parts: a theoretical part based on the literature review of the existing theories, background and analysis, and an empirical part based on field survey and interviews in the local context. Relevant 
literatures have been reviewed to determine the key concepts, background of the Mohammadpur Geneva camp settlement and developed an understanding to prepare a theoretical background in order to carry out the field survey and analyze the data.

To conduct the empirical part, the total sixteen students are divided into four groups consisting of four students. Each of the four groups collected information from different blocks of the camp and surveyed 100 households each. Thus a total number of 400 households from four different blocks surveyed by this process. Households were considered in a random selection basis to investigate the housing transformation and collection of data of different socio-cultural and economical attributes, which is the main premise of this study. The data collection was done with its main base in observational technique; supplemented by active participation, informal interviews, questionnaire survey, photographs and drawings.

Informal interviews alongside semi-structured interviews were taken of the inhabitants of the sample households chosen. The informal pattern of the questions also allowed the respondents to discuss their living patterns, employment, and income generation freely and with less inhibition. The conversations were all noted down and in some cases, taped for saving time. The field work was done at a time when the respondents were most active in their daily ventures to enable good photographs and sketches and even interviews with them.

The following attributes are being addressed for this study:

Table 1: Different type of attributes related to housing.

\begin{tabular}{|c|c|c|c|}
\hline Physical attributes & $\begin{array}{l}\text { Socio- } \\
\text { cultural } \\
\text { attributes }\end{array}$ & $\begin{array}{l}\text { Economic } \\
\text { attributes }\end{array}$ & $\begin{array}{l}\text { Community } \\
\text { attributes }\end{array}$ \\
\hline $\begin{array}{l}\text { Size of the house } \\
\text { Construction } \\
\text { materials } \\
\text { Construction of stair } \\
\text { Toilets and } \\
\text { sanitation condition } \\
\text { Water supply system } \\
\text { Waste disposal and } \\
\text { drainage system } \\
\text { Source of electricity } \\
\text { and fuel } \\
\text { Road network and } \\
\text { accessibility }\end{array}$ & $\begin{array}{l}\text { Size of } \\
\text { family } \\
\text { Family type } \\
\text { Age group } \\
\text { Gender } \\
\text { distribution } \\
\text { Religious } \\
\text { belief } \\
\text { Education } \\
\text { of the } \\
\text { inhabitants } \\
\text { House } \\
\text { Ownership }\end{array}$ & $\begin{array}{l}\text { Household } \\
\text { income } \\
\text { Occupation } \\
\text { Location of } \\
\text { workplace } \\
\text { Income } \\
\text { generating } \\
\text { activities in } \\
\text { home }\end{array}$ & $\begin{array}{l}\text { Roads and } \\
\text { paths } \\
\text { Spaces for } \\
\text { community } \\
\text { Religious } \\
\text { spaces } \\
\text { Education } \\
\text { spaces } \\
\text { NGO } \\
\text { activities } \\
\text { Community } \\
\text { activities }\end{array}$ \\
\hline
\end{tabular}

\section{Overview of the Settlement}

The Geneva camp is consisting of total 14.5 acres of land. The total settlement is distributed into 9 blocks. This blocks acts to identify the households for the community facilities. Though they are not works properly. The land on which Geneva Camp is built is owned by the Liaquat Housing Society. It is one of the few Camps where the land is still privately owned. Although Geneva Camp is located on private property, no rent is paid to the Liaquat Housing Society, as the community was considered internally displaced until the Dhaka High Court made its definitive decision in 2008.

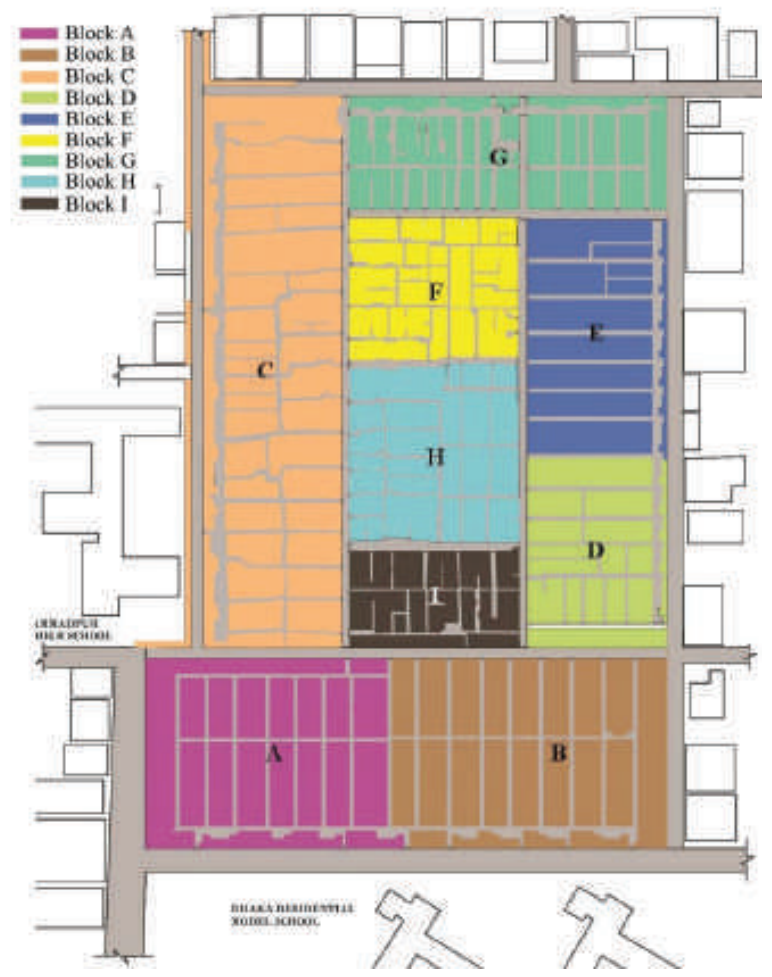

Figure 6: Division of nine blocks inside the camp.

More than 30 thousand people live in this camp. The density is 2100 person per acre which is beyond any housing standard of the world. there are 3843 houses (respondents' information) to accommodate this population. The over populated camp is like an island in the city. The inhabitants have no way to escape. They have to adjust their houses inside this confined settlement.

All the camps were highly crowded and the environmental scenario was hazardous. There was inadequate supply of basic facilities like water, 
electricity and gas. According to UN-HABITAT slum housing is 'households that lack decent water supply, adequate sanitation facilities, sufficient living area, decent structural quality and/or security of tenure' (UNHABITAT, 2003).

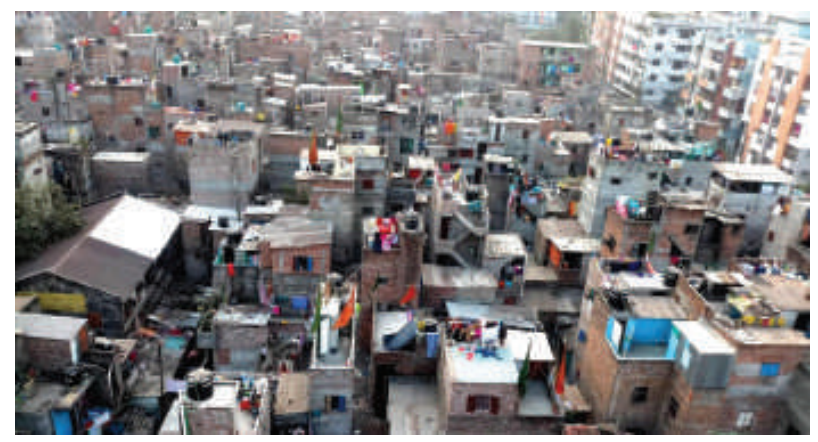

Figure 7: Panoramic view of Geneva camp. (Source: Field survey, 20191).

During the survey, the respondents shared their experiences in daily life where they faced problems due to their camp address. The general perception of these camps is 'den of poor people and evil doers' which often creates obstacle in sociopolitical inclusion of the Urdu speakers. In case of accessing the rights, their camp addresses put them in a vulnerable situation. Constant fear of eviction, difficulties in accessing important documents to improve livelihood options, lack of respect from noncamp dwellers- all these are linked with the fact that the country. Both these developments fulfilled their right to nationality which they had been lacking for more than three decades.

There are still dwellings with eight by six square feet area for eight to ten family members. Lack of access to water and poor sanitation are problems in every camp. Only two hundred toilets serve thousands of people and most of them are dirty and have no doors. Unclean water infects children with waterborne diseases; urinary tract infections affect women and girls. The lack of access to clean water makes it difficult for the people to maintain proper hygiene. There is no government health service in Geneva camp, and residents avail of medical services in a nearby government hospital (Iqbal et al., 2014). Some non-

\footnotetext{
${ }^{1}$ Unless otherwise specified, source of all figures, illustrations and plates are the field survey that took place in March 2019 by the Author along with the sixteen undergraduate students of Architecture Department of the Southeast University, Bangladesh.
}

governmental organizations (NGOs) provide medical service like vaccination for children.

The conditions in the camp are dire. Houses are separated by two-foot $(61 \mathrm{~cm})$ wide passageways shared by residents, goats and chickens. Houses are tiny, usually less than $8^{\prime} \times 8^{\prime}$, and host entire families. Residents raise their beds to make space for possessions underneath. When it rains, the camp floods, toilets overflowed.

The Geneva camp is a compact and confined living place for its inhabitants. Besides houses there are commercial activities, bazar, small retail shops and cottage industries, community clubs, restaurants, two large mosques and numerous small shrines, as well as two schools and a medical clinic run by the community-based NGO Al-Falah Bangladesh and some other social spaces inside the camp. Following figure shows different type of spaces or built forms in the existing layout plan of the camp.

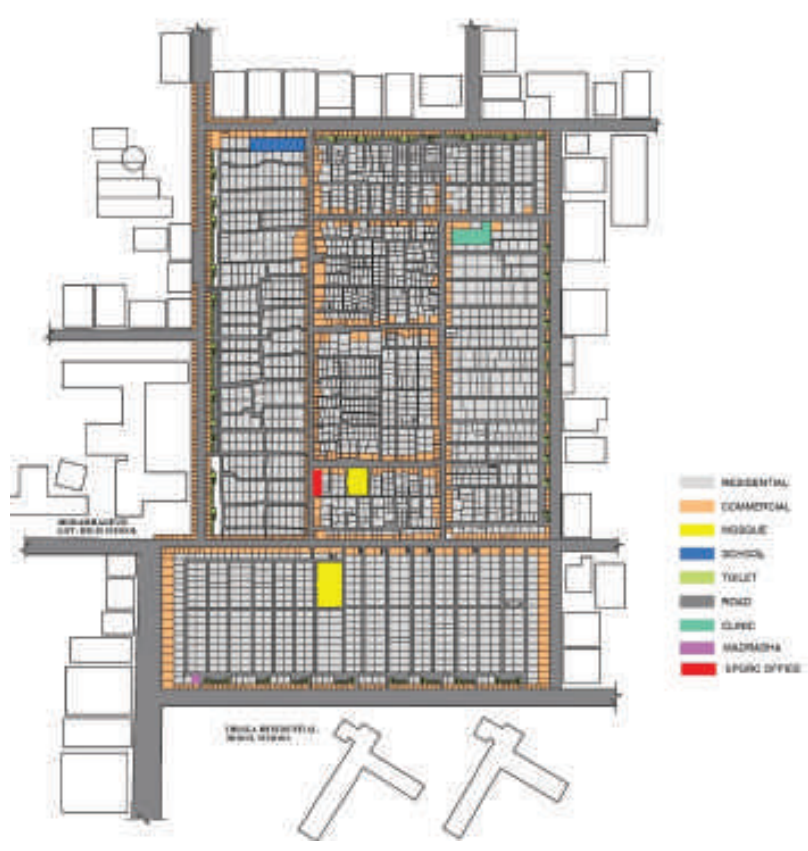

Figure 8: Different type of zones shown in the layout of the whole Geneva camp. (Produced with the help of CAD Mapper software).

Regarding the physical developments inside the camps, (which was closely related to the improvement of standard of living) most noticeable developments took place in Geneva camp after 2008. Many respondents said in interview that after 2008 a project 
was taken to provide clean water to Geneva camp and now people could drink water which was relatively clean without any bad smell. Approximately 30 to 40 new toilets were also built with water and electricity connection. These toilets were separated for both male and female residents of the camps. Twenty new rooms were built after a fire incident took place in the Geneva camp. It should be mentioned that these steps were taken by the local MP and Ward Commissioner of Mohammadpur area. The roads were constructed with cement, so there were more permanent in nature and more convenient to use. One male respondent claimed that physical developments inside the camps were initiated by the community people with help of some NGOs. Government did not play any role at all.

\section{Housing Problems with different Livelihood Attributes}

Housing generally refers to the social problem of ensuring that members of society have a home in which to live, whether this is a house, or some other kind of dwelling, lodging, or shelter. Housing is a paradigm that interconnected with many attributes. In the settlement of Geneva Camp, the crisis of housing is related to such many attributes. In this section these attributes are addressed after the findings of the field survey.

\subsection{Physical Attributes}

Physical attributes are comprising of the footprint of house, building height, construction materials, construction of stair, toilet/ bathroom, source of water, source of power, electrical equipment, source of fuel, waste disposal system, sanitary system, condition of roads and paths, multidimensional use of house etc.

\section{Size of the house}

The houses of camp are semi-pucca. The average size of a room is 80 square feet. Generally, three types of module for house footprint found during the field survey. They are: 8'X8', 8'X10'and 10'X12'. There are few number of houses which have a footprint of less than 8'X8'. The percentage of different size of houses in the surveyed 400 houses are shown in the following chart.

\section{Footprint of house}

\begin{tabular}{|ll|}
\hline $\begin{array}{l}\text { House size } \\
\text { Smaller } \\
\text { than } 8^{\prime} \mathrm{X} 8\end{array}$ & Percentage \\
$8^{\prime} \mathrm{X} 8$ & $10 \%$ \\
$8^{\prime} \mathrm{X} 10 '$ & $34 \%$ \\
$10^{\prime} \mathrm{X} 12$ & $18 \%$ \\
$\begin{array}{l}\text { Larger than } \\
10^{\prime} \mathrm{X} 12\end{array}$ & $8 \%$ \\
\hline
\end{tabular}

Figure 9: Percentage of different size of houses.

Leading a family life in such a small space is really difficult. In half of the families. three-generations live under the same roof. The position of bed is made high to protect it from flood. A little rain creates water logging. Respondents informed that in dry season some members sleep under the bed. There are variations in internal layouts in this small piece of house. People always have to explore the best fit for their accommodation and other purpose. Some layouts are shown in the following figure.
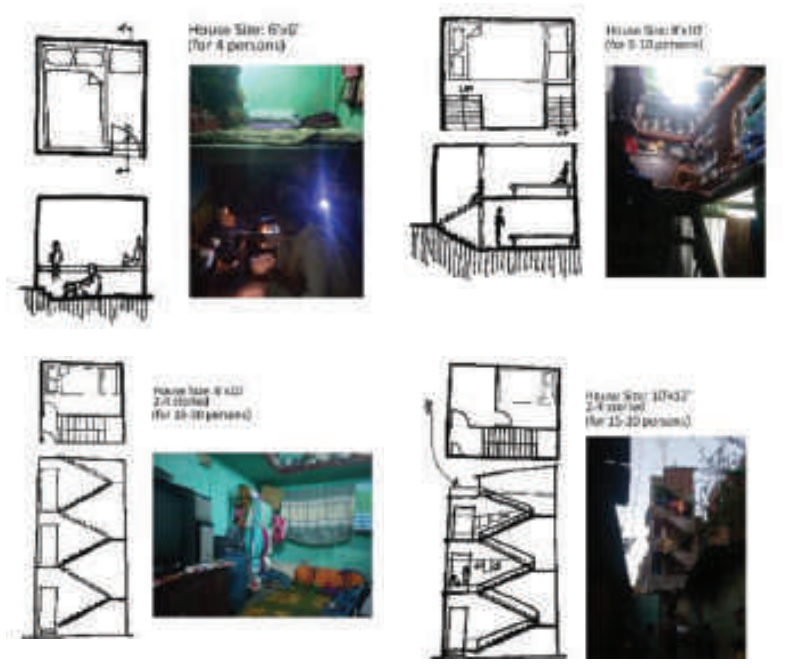

Figure 10: Different type of internal arrangement of the rooms.

Most of the houses consist of one room. Some of the inhabitants reside in multiple storied buildings. They have one room in each floors. The staircases of these multistoried buildings are so narrow that it is impossible for more than one person to climb at a time. 


\section{Building height}

\begin{tabular}{|c|c|}
\hline $\begin{array}{l}\text { Building } \\
\text { height }\end{array}$ & Percentage \\
\hline $\begin{array}{l}\text { Single } \\
\text { storied }\end{array}$ & $14 \%$ \\
\hline 2 storied & $23 \%$ \\
\hline 3 storied & $28 \%$ \\
\hline 4 storied & $23 \%$ \\
\hline $\begin{array}{l}\text { More than } 4 \\
\text { storied }\end{array}$ & $12 \%$ \\
\hline
\end{tabular}

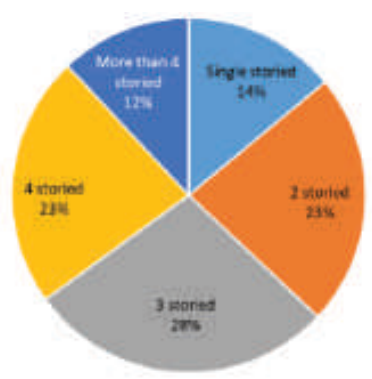

Figure11: Percentage of houses of different height.

\section{Construction materials}

There are both pucca and semi-pucca building are in the Geneva camp, though most of them are multistoried. They use thin R.C.C. (Reinforced Cement Concrete) structure and 3" thick clay burnt brick wall. Most of the surfaces are not plastered or painted. During construction they first make the walls on four sides and then cast slab over it. The use of CI (Corrugated Iron) sheet is very wide. It is mainly used for top roofing and sometimes for surface also.

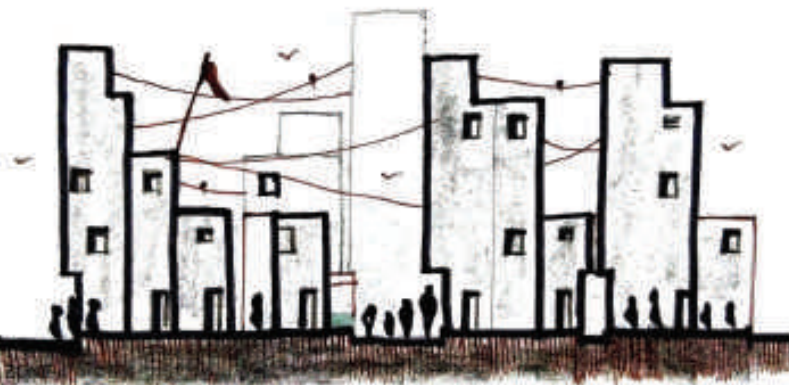

Figure 12: Sketch showing houses with different height. (Source: Field survey 2019).

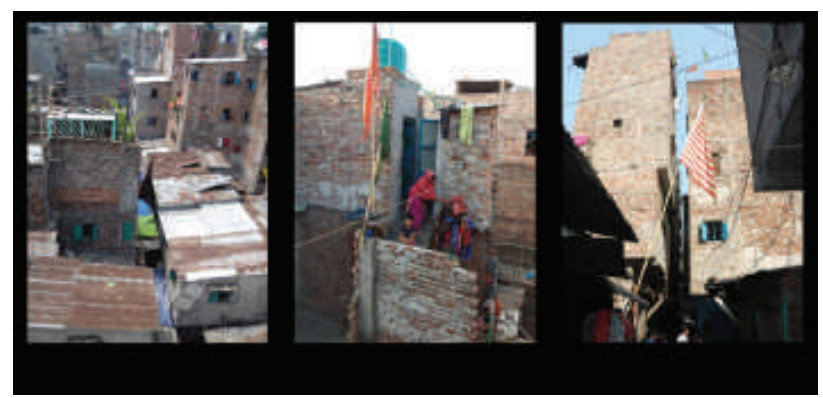

Figure 13: Use of different construction materials. (Source: Field survey 2019).

\section{Construction of staircase}

The staircases of the multi storied buildings are so narrow that it is impossible for more than one person to climb at a time. There is no ideal measurements for making stairs. During the field survey, the height of riser found is 8 inch to 18 inch and the depth of tread found is 7 inch to 10 inch. Most of the cases stairs are constructed by R.C.C.

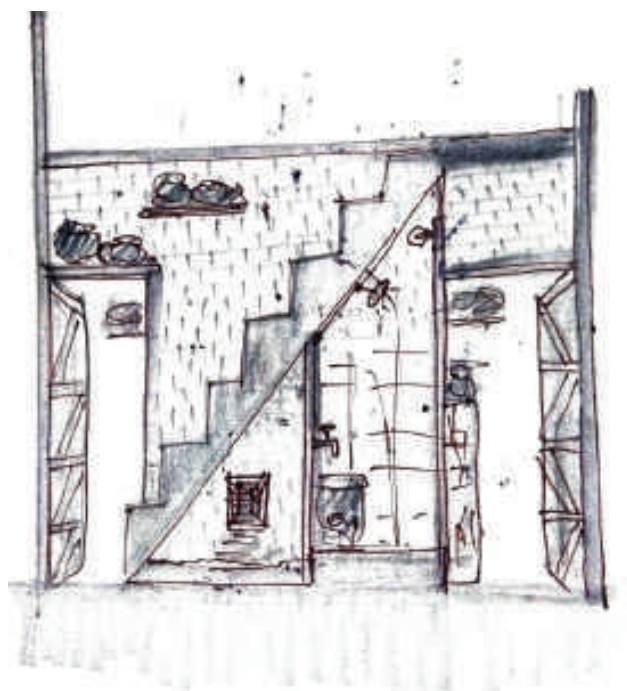

Figure 14: Section showing an arrangement of stair in a house.

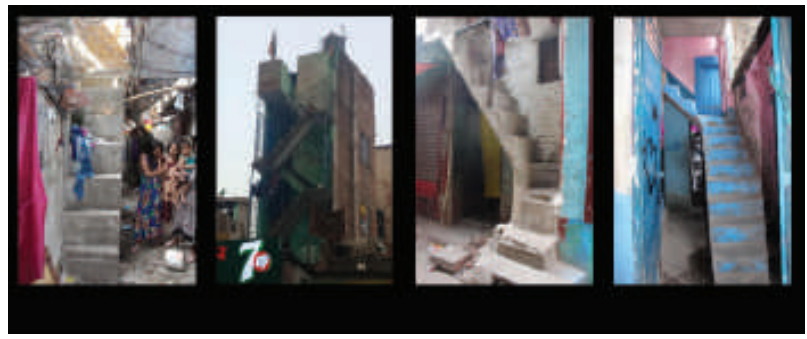

Figure 15: Examples of staircases in the multistoried buildings. (Source: Field survey 2019)

\section{Toilets and sanitation condition}

Every house does not have individual toilet system. They use toilet at the common toilet block. In a toilet block there are 7 toilets, 3 for male and 4 for female. There are a total 261 toilets in the camp. A large number of these toilets are unusable. The bathrooms are open. There are no toilets in block $-\mathrm{H}$ and I of the camp. The residence of those blocks use the toilets of block -C. On an average each toilet is used by 100 people, but nearly $50 \%$ of toilets are out of order, so 
the average number of people using each toilet is closer to 200. Most of the common bathrooms are very unhygienic in the area. In addition, the entire camp people share a few common bathrooms and toilets, which are very few compared to the number of people. Most of the time they need to queue to get their turn. Furthermore, both male and female alike share the same facility, which creates problems for the females. There is no privacy for the females either in toilet or shower facilities. Most of the toilets are without shade, and people need to stand in line for their turn. In the shower rooms ladies sometimes have to wait for hours to take bath in groups of three or four.

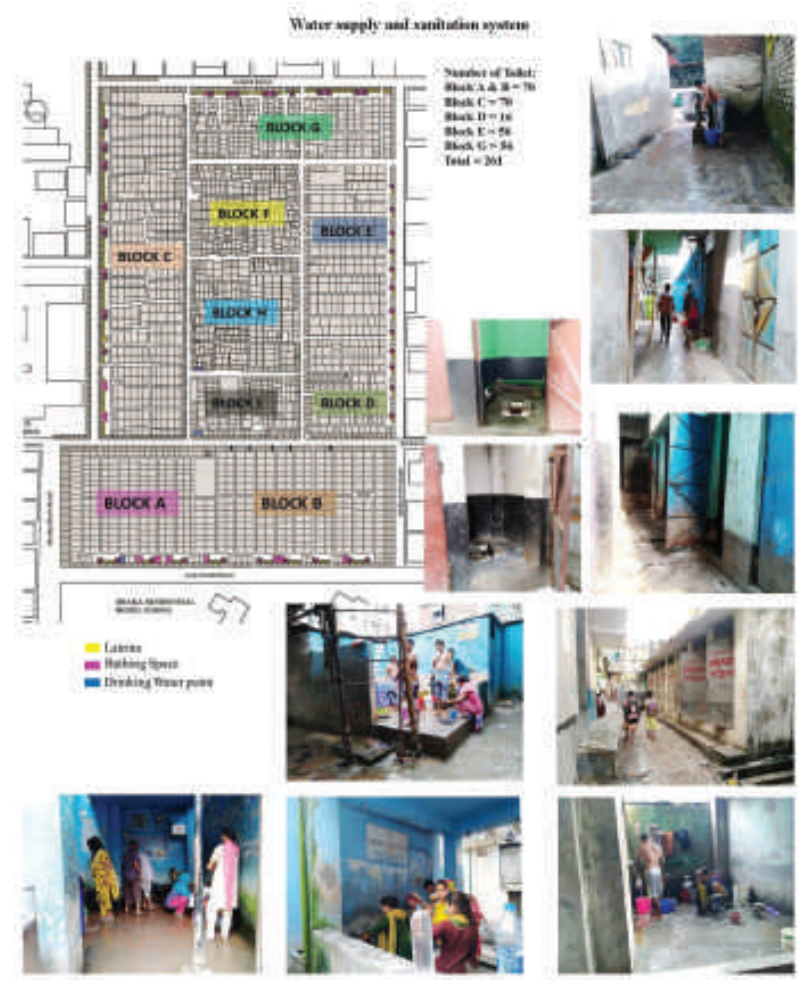

Plate 1: Condition of water supply and sanitation system of Geneva camp.

A growing trend in Geneva Camp is for families to build their own private toilets, but due to the cramped living conditions few have the space to do this inside their homes. Many multistoried houses built private toilet on the rooftop. Aged people and children often use open drains as toilet at night. These drains remain full of garbage. Actually there is no complete drainage or sewerage system. Some better off families have built toilets in their living room (about 9 square feet in size).

\section{Water supply system}

In the whole camp there are approximately 35 tubewell and there are only three drinking water points. This tube-well are maintained by an NGO called OBAT. Though there is a water supply pump in each block but the water is not hygiene and available all the time. For this reason prefer to have their own water pumps to collect water from underground due to the long lines and over use of public ones, yet because of the space constraints few have had the scope to do so. As for the public water pumps, there is at least one in each sector of Geneva Camp with some of the larger sectors having two. The public pumps are not only used for water collection but also for bathing and clothes washing, which adds to the areas' congestion. Drinking water is carried from the pumps to individual homes in metal or plastic buckets and then stored in large drums near the stove or under the bed. The water gathered from the public taps in each sector is free of charge. There is another supply line provided by the government authority WASA. Some household arranged illegal water connections from WASA pipeline. Water comes from the city line is subject to being shut off for part of the day, especially during the dry season.

Source of water
\begin{tabular}{|ll|}
\hline Water source & Percentage \\
\hline Hand pump & $60 \%$ \\
\hline Deep tube-well & $25 \%$ \\
\hline $\begin{array}{l}\text { WASA pipe } \\
\text { line }\end{array}$ & $15 \%$ \\
\hline
\end{tabular}

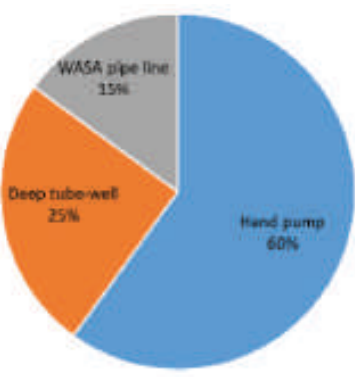

Figure 16: Dependency on different source of water.

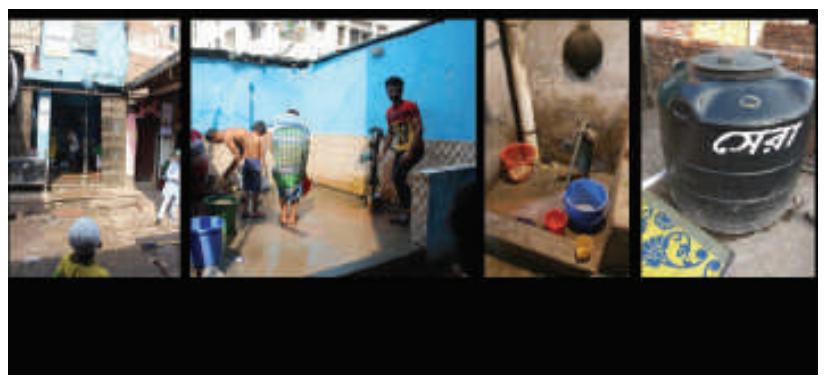

Figure 17: Different sources of water. 
Some respondents complained that water coming from the pumps contains a high level of iron and other heavy metals and has bad odor. Inhabitants need to treat the water to make is suitable for drinking. Survey shows that, $19 \%$ of respondents have their own water filter for household use. $9 \%$ households collect water from central drinking water points which is called 'patal' in the local language. And $72 \%$ of households purify water through boiling.

\section{Source of drinkable water}

\begin{tabular}{|ll|}
\hline Source & Percentage \\
\hline $\begin{array}{l}\text { Private water } \\
\text { filter }\end{array}$ & $19 \%$ \\
\hline $\begin{array}{l}\text { Central point } \\
\text { for drinking } \\
\text { water }\end{array}$ & $9 \%$ \\
\hline Boiling & $72 \%$ \\
\hline
\end{tabular}

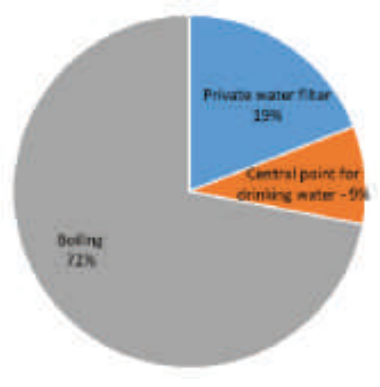

Figure 18: Source of drinkable water.

\section{Waste disposal and drainage system}

Garbage disposal in Geneva Camp takes many forms. Waste water created while cooking is typically dumped directly into the alleyways or into the infrequent above-ground drains, while solid-food waste is disposed of in intermittently available trash bins or in informal piles. The City Corporation removes garbage from Geneva Camp on a weekly basis from two large trash bins located on the periphery of the Camp. Respondents said that, the Dhaka North City Corporation (DNCC) does not clean the garbage insidethe camp. Neither do they spray medicine to protect the area from mosquito.

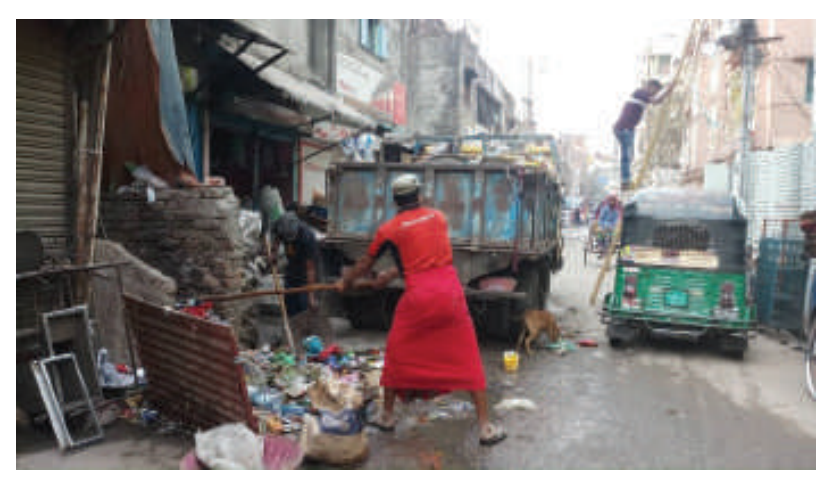

Figure 19: Weekly garbage collection by the municipality.

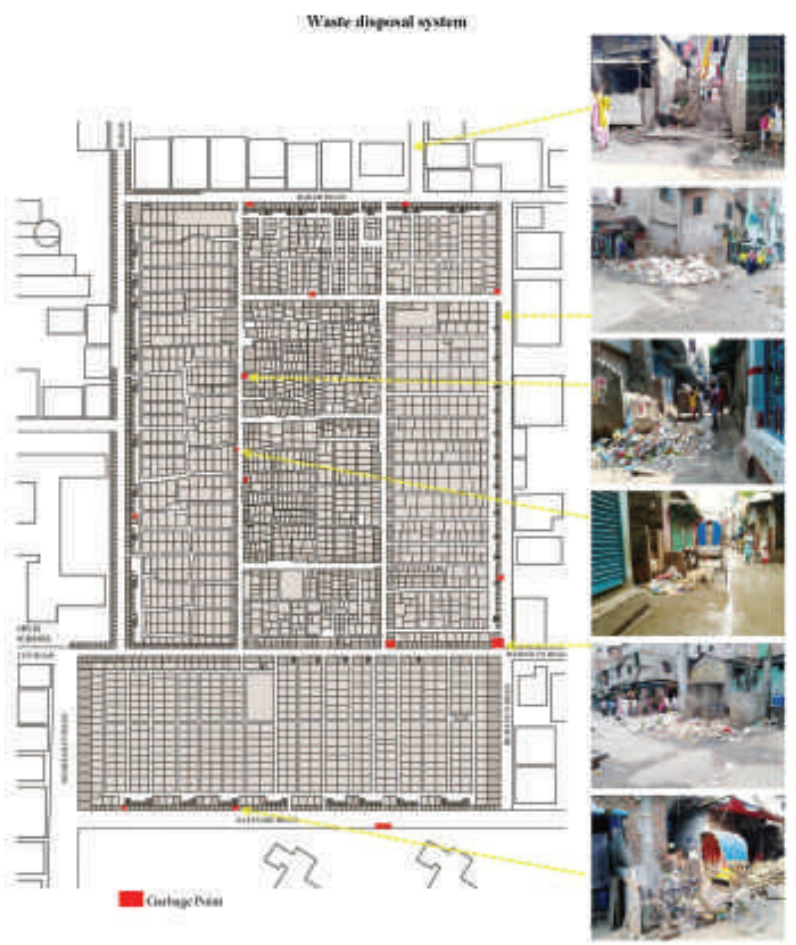

Plate 2: Condition of waste disposal system of Geneva camp.

There is no house found that have a proper sewerage system. There is no septic tank for the private toilets. The solid and liquid both sanitary wastes goes to the surface drain. Many people had a few ideas about personal hygiene. Though day by day they are getting knowledge about hygiene with the help of the government organizations, NGOs, and media broadcastings. The concepts of remain hygiene now accepted by the community of Geneva camp. Most of the people believe that the hygienic practice can improve their lives. But lacks of proper opportunity the environment remains unhygienic. Specially the open drain and open garbage dumping makes the environment more unhygienic.

As the population density is very high the living environment of the camps is very deplorable. It is unhealthy, dirty, damp and un-hygienic. The camp authorities are neither able nor serious to maintain a healthy sanitation facility. The drainage system is extremely poor, which causes water logging very easily. Therefore, contagious diseases especially diarrhea and dengue are very common. The municipalities/City Corporation cleaners never enter the camps to clear the garbage. It is only when the camp-dwellers drop their 
garbage in the dustbins outside the camp that the City Corporation cleaners will take them out. So this can be stated than the insufficient, unhealthy water supply, poor sanitation structure and low hygiene facilities make worse situation of life in the Geneva camp.

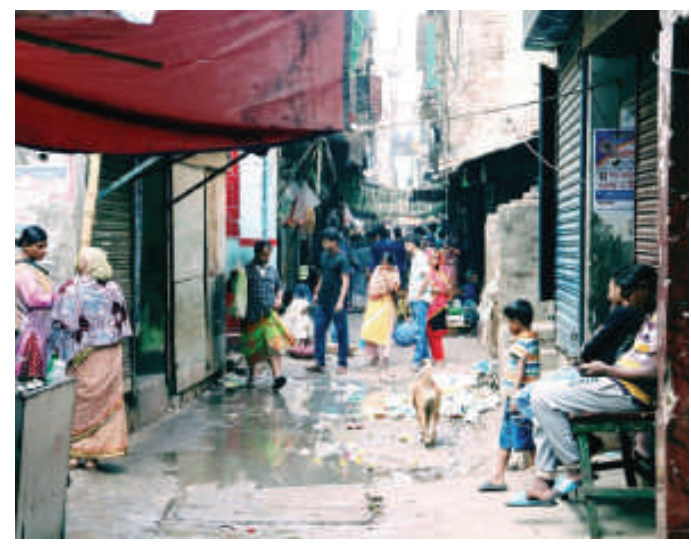

Figure 20: Over flowing of surface drain.

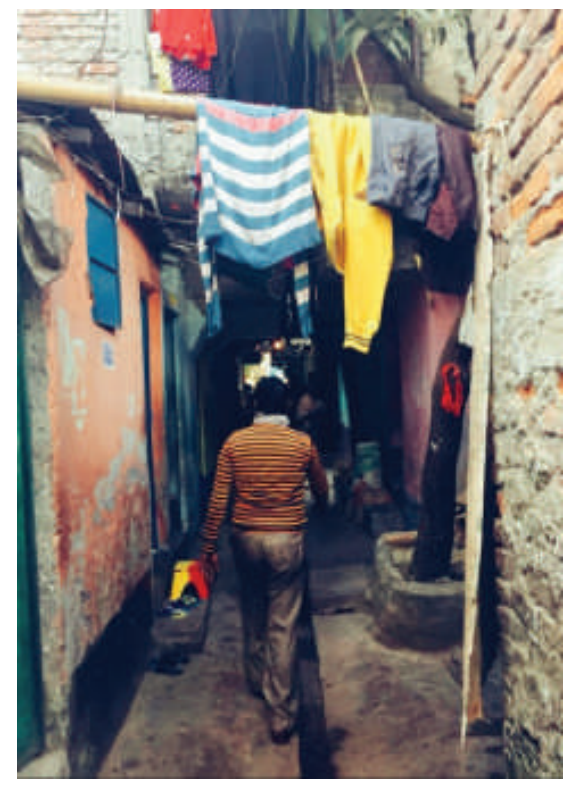

Figure 21: Surface drain in narrow pathway.

\section{Source of electricity and fuel}

It is found that $100 \%$ households of Geneva camp have electricity connection in their house. The supply of electricity is from DESCO (the government authority who supply electricity in Dhaka city). Electricity is free of charge in Geneva Camp, but its actual availability depends on the resources of the supplying company. During the summer months, the hours of electricity outage often outweigh the number of hours it is available. Bangladesh Red Crescent Society pays the electricity and water bills. But some of the residents claimed that they pay the bills. The consumption of electricity is not that much less in the camp. Now a day most of the houses have refrigerators, televisions, audio system, rice cookers etc. besides necessary equipment like light, fan etc. Many houses have water pump for their own to pump water to the overhead reservoir.

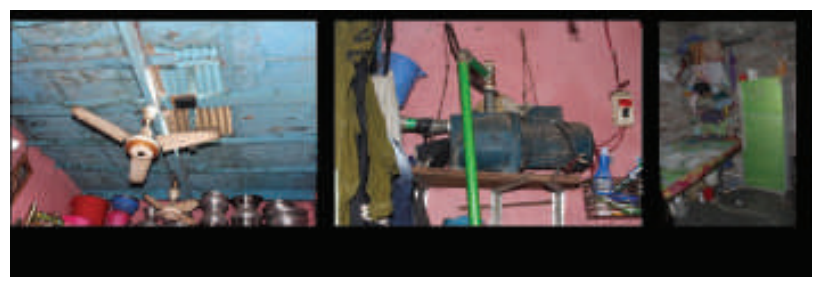

Figure 22: Some electrical equipment that are available in most of the houses.

There is no gas connection from city line. So they use LPG (Liquefied Petroleum Gas) cylinder, kerosene and wood for cooking. LPG is a gas which has been converted into a liquate containing propane and butane, at low pressures and moderate temperatures, often after the cracking process. As the kerosene is expensive, most families go through one can of kerosene each day just cooking food. Survey shows that, $26 \%$ of families use LPG Cylinder, $44 \%$ use Kerosene and $22 \%$ of households use wood or coal as fuel for cooking purpose. Apart from this, electricity also used as a source of power for rice-cooker in many families in $8 \%$ households.

They cook both inside and in front of the living room. The cooking is very difficult and unhygienic for whom they cook inside room and outside the room in shared cooking places. As they used Kerosene and wood it create smoke and odor which also unhygienic.

\section{Use of fuel}

\begin{tabular}{|ll|}
\hline Fuel type & Percentage \\
\hline LP Gas & $26 \%$ \\
\hline Kerosene & $44 \%$ \\
\hline $\begin{array}{l}\text { Wood and } \\
\text { Coal }\end{array}$ & $22 \%$ \\
\hline Electricity & $8 \%$ \\
\hline
\end{tabular}

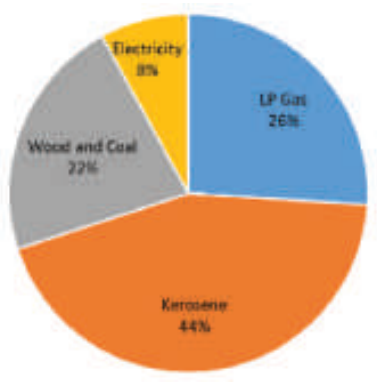

Figure 23: Use of different types of fuel. 


\section{Road network and accessibility}

Different roads with different type and size are in the Geneva camp. The surrounding roads are 40 feet and 25 feet width. They are maintained by the municipality. The internal roads those are dividing different blocks are 12 to 15 feet in width. There are some narrow roads inside the camp are 8 to 10 wide. But most of the internal pathways are 3 to 6 feet wide pedestrian. These narrow pedestrians are like web all over the camp. Sometime buildings from both side are extended over the narrow pathways. Survey shows that total roads and paths occupy 13\% land of the whole camp. These $13 \%$ spaces are also the breathing space for the community.

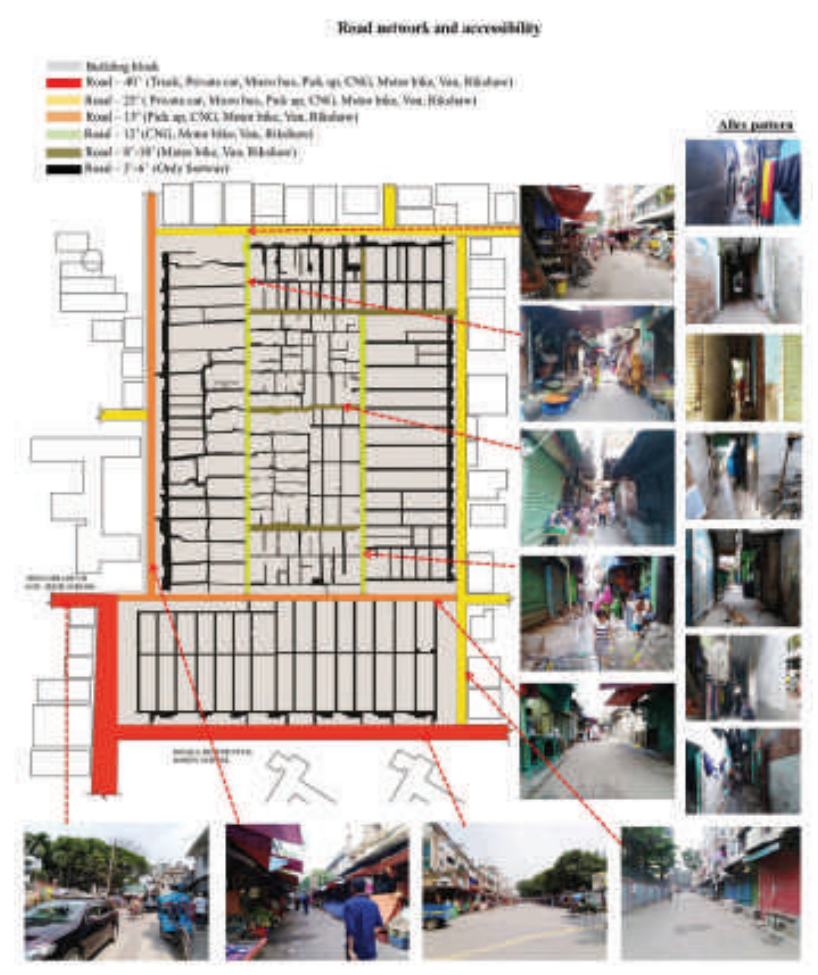

Plate 3: Condition of Road network and accessibility in Geneva camp.

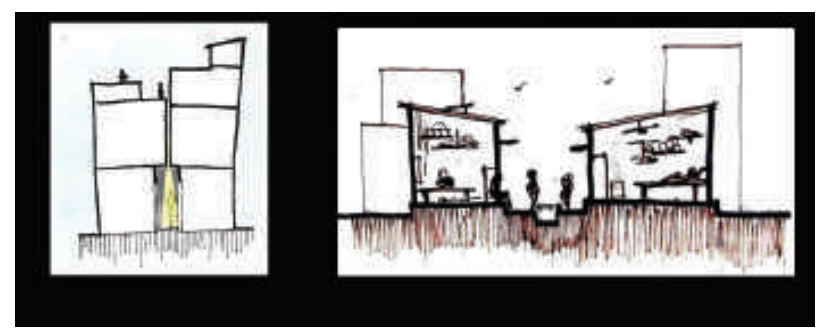

Figure 24: Narrow pathway in between the houses.

\subsection{Socio-Cultural Attributes}

Socio-cultural attributes are comprising of the size of family, family type, religious belief of the inhabitants, their age group, gender, education of the family members, domestic animal/pet etc. These attribute play roles over the livelihood of the settlement.

Family size varied in the population of Geneva camp. It is found to study 400 hundred families that $30 \%$ respondents have $3-5$ members in their family. $41 \%$ have 6-8 members, $25 \%$ have more than 8 members in their family and only $4 \%$ have less than 3 members in their family.

Family size

\begin{tabular}{|ll|}
\hline $\begin{array}{l}\text { Nos. of } \\
\text { members }\end{array}$ & Percentage \\
\hline $\begin{array}{l}\text { Less than } 3 \\
\text { persons }\end{array}$ & $4 \%$ \\
\hline $3-5$ persons & $30 \%$ \\
\hline 6-8 persons & $41 \%$ \\
\hline $\begin{array}{l}\text { More than } 8 \\
\text { persons }\end{array}$ & $25 \%$ \\
\hline
\end{tabular}

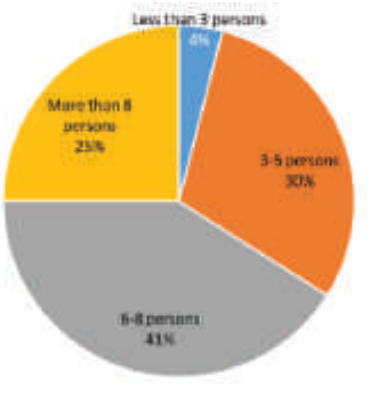

Figure 25: Ratio of family size.

Most of the families are joint by nature. There are 68\% of the 400 respondents are living in a joint family and $29 \%$ are living in single or nuclear family. There are few respondents found who are bachelor and live as tenants inside the camp.

Type of family

\begin{tabular}{|ll|}
\hline Type & Percentage \\
\hline Single family & $29 \%$ \\
\hline Joint family & $68 \%$ \\
\hline Others & $3 \%$ \\
\hline
\end{tabular}

Figure 26: Comparison of the type of family.

It is found from the field survey that, $14 \%$ of the inhabitants are below the age of 10 years. $22 \%$ people are between $10-18$ years age, $31 \%$ people are between 40-60 years age and 9\% people have an age of above than 60 years. 
Age group of the inhabitants

\begin{tabular}{|l|l|}
\hline Age range & Percentage \\
\hline $0-10$ years & $14 \%$ \\
\hline $10-18$ years & $22 \%$ \\
\hline $18-40$ years & $31 \%$ \\
\hline $\begin{array}{l}\text { 40-60 years } \\
\text { Above } 60 \\
\text { years }\end{array}$ & $24 \%$ \\
\hline
\end{tabular}

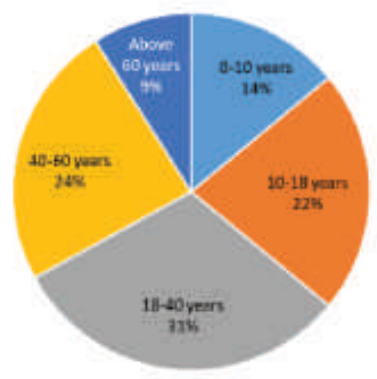

Figure 27: Ratio of the inhabitants' age group.

From the survey among 400 families it is found that the male population is higher than the female population. Male population is $53.5 \%$ in the camp.

Gender distribution
\begin{tabular}{|l|l|}
\hline Gender & Percentage \\
\hline Male & $53.5 \%$ \\
\hline Female & $46.5 \%$ \\
\hline
\end{tabular}

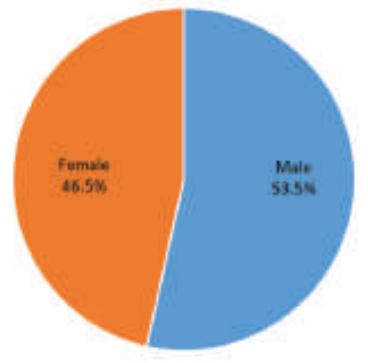

Figure 28: Gender distribution ratio.

All the inhabitants of the Geneva camp are Muslim. Though there are two type of believes among them. Majority belongs to the belief of Sunni Muslims. It is found by the field survey that there are $96 \%$ people have the belief of Sunni and only $4 \%$ have the belief of Shia. Though by seeing the activities and religious festival of Ashura outside people thing them as Shia believers.

\section{Religious belief}

\begin{tabular}{|l|l|}
\hline Religion & Percentage \\
\hline $\begin{array}{l}\text { Sunni } \\
\text { Muslim }\end{array}$ & $96 \%$ \\
\hline Shia Muslim & $4 \%$ \\
\hline
\end{tabular}

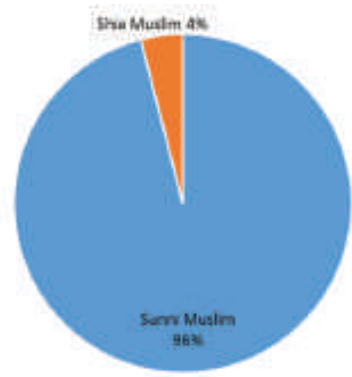

Figure 29: Ratio of the inhabitants' religious belief.
6\% people of the Geneva camp do not have any education. $64 \%$ of total respondents have completed primary level education. $18 \%$ have educational qualification up to secondary school (Class 10) level $10 \%$ respondents have an educational qualification up to higher secondary (Class 12 ). There are only $2 \%$, who got the chance to go for tertiary level education. Most of the children of the camp go to school. More girls than boys go to school. Boys generally leave school after class 5 while girls are leaving after class 7 or 8 . The main reason behind the drop out is the affordability. They hide their identity to get admission to the schools. Students use false address instead of their camp address.

They have problems of enrolment in educational institution due to identification of nationality. The expense of education including the cost of educational materials (books, paper, pen etc) is high for them. Lack of security is also a reason.

\section{Education of the} inhabitants

\begin{tabular}{|l|l|}
\hline Level & Percentage \\
\hline No education & $6 \%$ \\
\hline Primary & $64 \%$ \\
\hline $\begin{array}{l}\text { SSC (Class } \\
10)\end{array}$ & $18 \%$ \\
\hline $\begin{array}{l}\text { HSC (Class } \\
12)\end{array}$ & $10 \%$ \\
\hline Tertiary & $2 \%$ \\
\hline
\end{tabular}

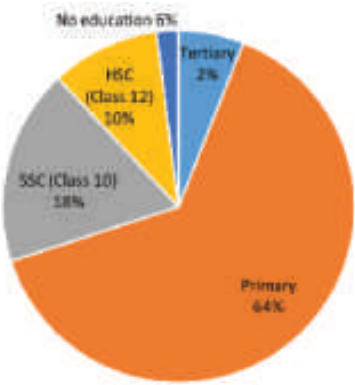

Figure 30: Ratio of inhabitants with different level of education.

Most of the inhabitants are the owner of their house. $82 \%$ people lives in their own house. Rest $18 \%$ are the tenants who has to live inside the camp, or they have house inside the camp also I different location.

House ownership
\begin{tabular}{|l|l|}
\hline $\begin{array}{l}\text { Ownership } \\
\text { type }\end{array}$ & Percentage \\
\hline Rental & $18 \%$ \\
\hline Owner & $82 \%$ \\
\hline
\end{tabular}

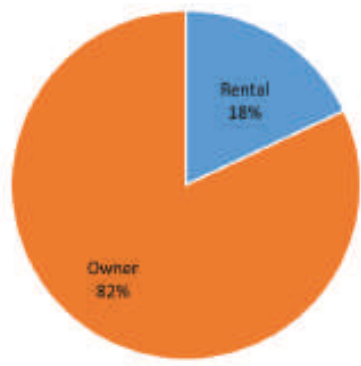

Figure 31: Ratio of inhabitants'ownership of the house. 


\subsection{Economic Attributes}

Monthly household income of the Geneva camp is very low. Most of the cases, there are multiple members of a family are income generating persons. Their combined income is considered as the household income. It is very common in the Geneva camp that family members earn a little individually and all small amounts they earn, contributes to their family.

Survey shows that $25.5 \%$ family has a household income below 10,000 Taka and only 30\% has a household income more than 30,000 Taka. $42 \%$ family has an income ranging from 10,000-20,000 Taka per month and $19.5 \%$ family has an income ranging from 20,000-30,000 Taka per month.

Household income
\begin{tabular}{|l|l|}
\hline $\begin{array}{l}\text { Monthly income } \\
\text { (BDT) }\end{array}$ & Percentage \\
\hline Bellow 10,000 & $25.5 \%$ \\
\hline $10,000-20,000$ & $42 \%$ \\
\hline $20,000-30,000$ & $19.5 \%$ \\
\hline Above 30,000 & $13 \%$ \\
\hline
\end{tabular}

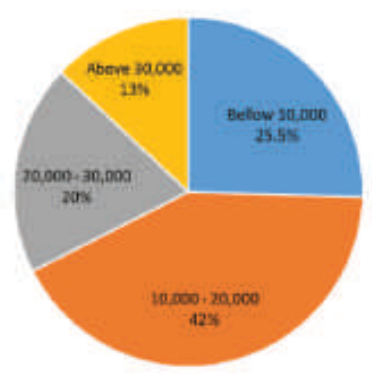

Figure 32: Ratio of monthly household income of the inhabitants.

One of the major occupations of the respondent is handicraft, which includes different type of boutique works, tailoring, karchupi and related work. Most of the family members including women and children are involved in income generating activities such as invarious handicrafts, shop keeping and selling homemade food item. There are some service holders mostly in nongovernment service. Some female members work as maid in home or organization outside the camp. Some male-headed households working as motor mechanics, drivers or caterer. There are many entrepreneur of small business found through the field survey.

It is found by the field survey that $21 \%$ dwellers are engaged with boutique and handicrafts. $16.5 \&$ dwellers work as shop keeper or retailers. $15.5 \%$ people are tailor, $10.5 \%$ are motor mechanic, $9.5 \%$ work as maid or labor in outside the camp, $9 \%$ have food business, $4.5 \%$ are butcher, another $4.5 \%$ are barber andrest $9 \%$ people are engaged with different type of job outside the camps.

\section{Occupation of the inhabitants}

\begin{tabular}{|l|l|}
\hline Occupation & Percentage \\
\hline Boutique & $21 \%$ \\
\hline $\begin{array}{l}\text { Shop keeper/ } \\
\text { Retail }\end{array}$ & $16.5 \%$ \\
\hline $\begin{array}{l}\text { Tailor } \\
\text { Motor } \\
\text { mechanic }\end{array}$ & $15.5 \%$ \\
\hline Maid/ labor & $9.5 \%$ \\
\hline $\begin{array}{l}\text { Cook/ } \\
\text { restaurant }\end{array}$ & $9 \%$ \\
\hline Butcher & $4.5 \%$ \\
\hline Barber & $4.5 \%$ \\
\hline Others & $9 \%$ \\
\hline
\end{tabular}

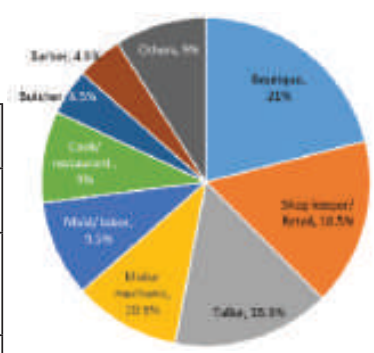

Figure 33: Ratio of the different occupation of the inhabitants.

$19 \%$ camp inhabitants have their workplace inside or adjacent to their living place and another $47 \%$ camp inhabitants works inside the camp. 34\% people have their workplace outside the camp.

\section{Location of workplace}

\begin{tabular}{|l|l|}
\hline Location & Percentage \\
\hline $\begin{array}{l}\text { Inside the } \\
\text { camp }\end{array}$ & $47 \%$ \\
\hline $\begin{array}{l}\text { Outside the } \\
\text { camp }\end{array}$ & $34 \%$ \\
\hline $\begin{array}{l}\text { Adjacent to } \\
\text { house }\end{array}$ & $19 \%$ \\
\hline
\end{tabular}

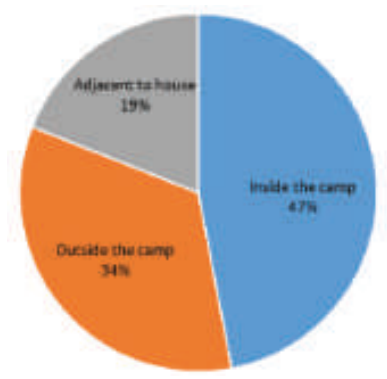

Figure 34: Location of the workplace of the inhabitants.

Home is sometimes used for several purposes beside living. As livelihood is a great challenge for the camp inhabitants many of them are involved for different income generating activities. In the roadside houses, the ground floors are used as a shop or other commercial spaces in most of the cases. People are using their living place for some periodic activities also. The same place of sleeping is used for income generating actives at day time. 


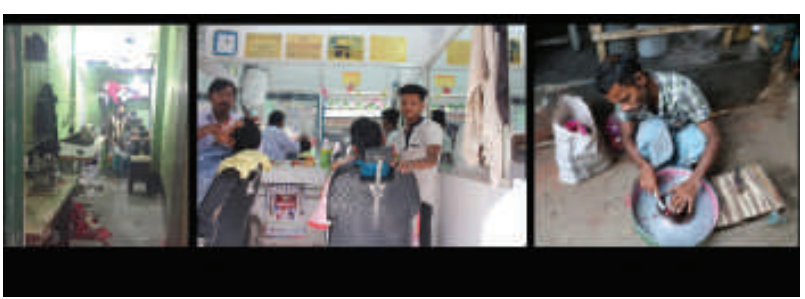

Figure 35: Income generating activities at home and adjacent to home.

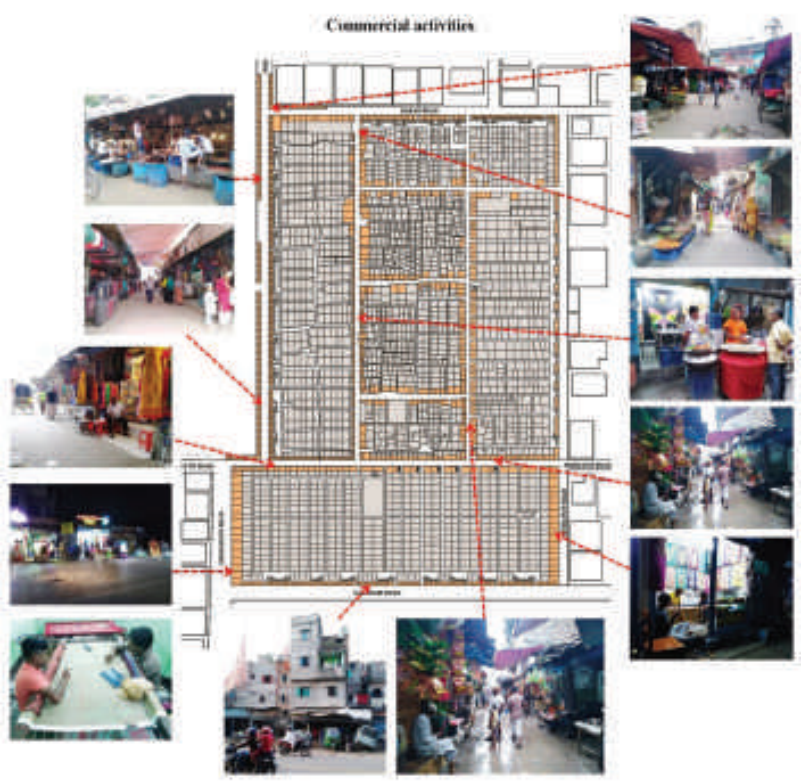

Plate 4: Commercial activities inside the camp.

Commercial activities are the part and parcel of camp life. There are different types of shops and commercial spaces all over the camp. The wider the road, the busier market place for both the camp dwellers as well as for the outsiders.

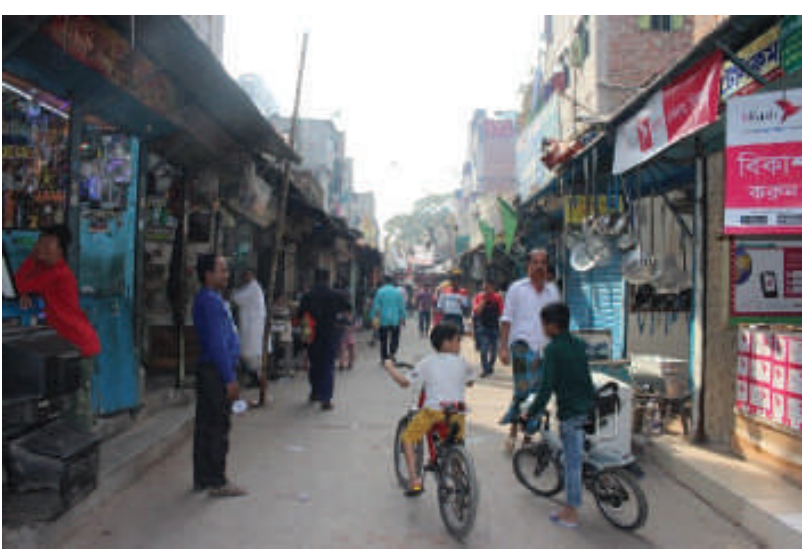

Figure 36: Business district inside the camp.
Animal husbandry is another common feature in the Geneva camp. Most of the camp dwellers have birds or animal. Pigeon is very common. Many camp dwellers have pigeon as a hobby. Many have goats and rabbits. Though they have very little space for those, they accommodate those beneath the staircase or on the roof top.

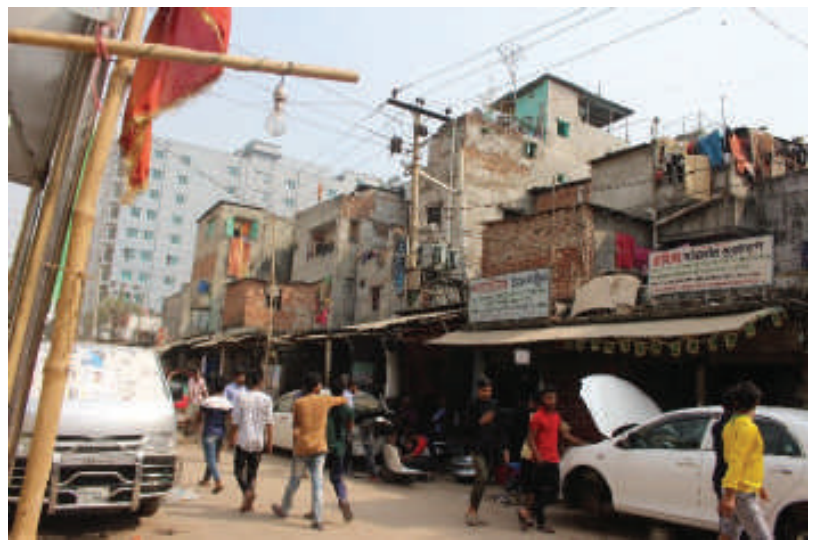

Figure 37: Motor workshops adjacent to the camp.

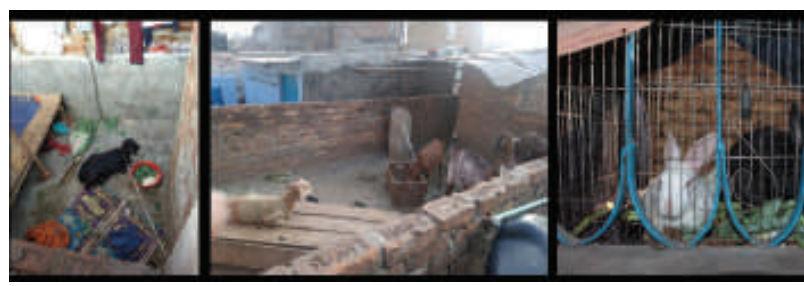

Figure 38: Keeping pet is a common hobby for camp dwellers.

\subsection{Community Attributes}

There are merely any dedicated social or community space inside the camp. The roads are the main place for community gatherings. Doorsteps inside narrow aisles are the place for social interaction for the dwellers. Camp side roads and in front of different community spaces are also acts as social activity spaces.

Geneva Camp contains two large mosques and numerous small shrines locally called Imambara (some ritual structure of Shia Muslim. But these are also built and used by Sunnis in the camp).

There aretwo schoolsinside the camp. The school is up to class 10 level in two different shifts. Total student capacity is around 900 in total. The schools 
are used as community center on Fridays. There is an Urdu medium madrasa inside the camp.

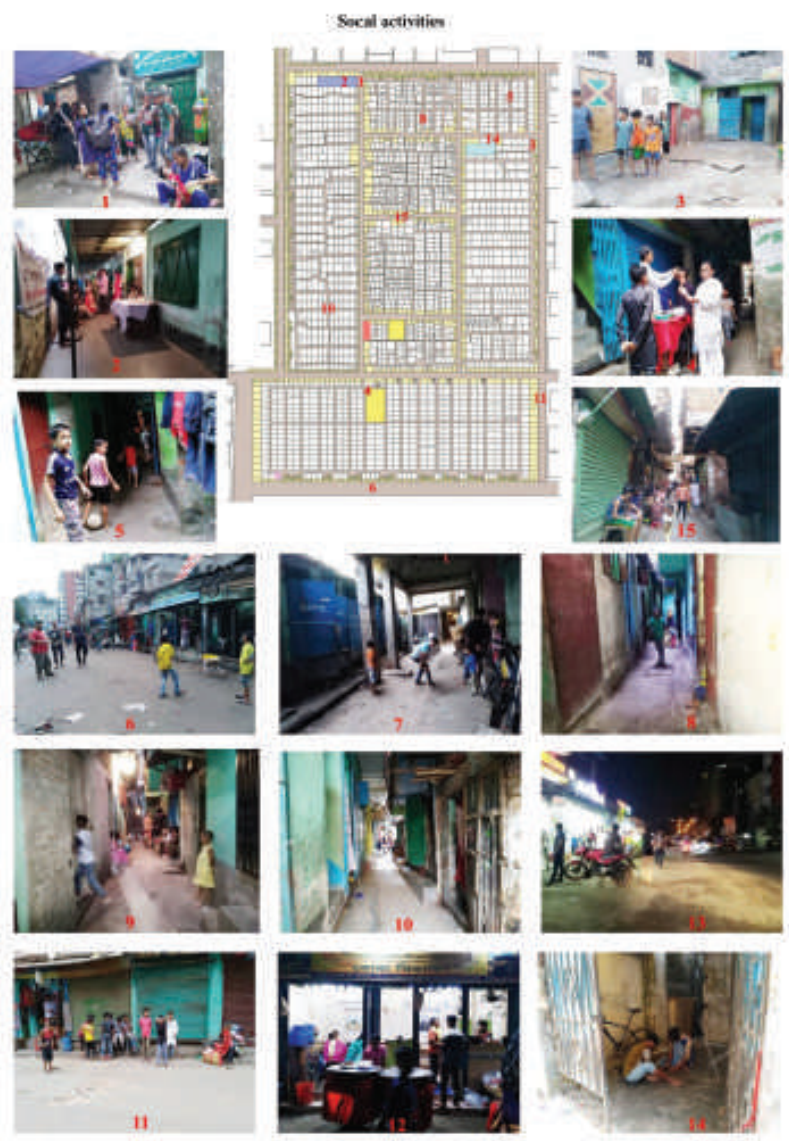

Plate 5: Social activities inside the camp.

Densely populated environment, filthy water and lack of proper sanitation cause various disease inside the camp. Though there is a clinic inside the camp, camp dwellers need to go outside for treatment. There are few medicine shops inside the camp where first aid and easy checkup for diabetics and blood pressure is available. The medical clinic is run by the communitybased NGO Al-Falah Bangladesh.

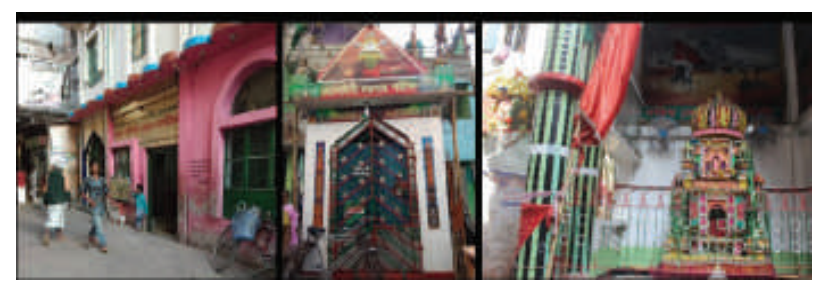

Figure 39: Some religious spaces inside the Geneva camp.

Non-governmental organizations- commonly referred to as NGO are usually non-profit. There are some local and foreign NGOs that help the comp dwellers. Such as, OBAT, Ahmed Foundation, Al Falah Foundation and ASA. They are working in different sectors like, sanitations and hygiene, drinking water, education, micro-credit, family planning, medical support, uplifting life standard etc. There are associations and clubs inside the camp for its inhabitants. NLRC and SPJRC are two clubs.

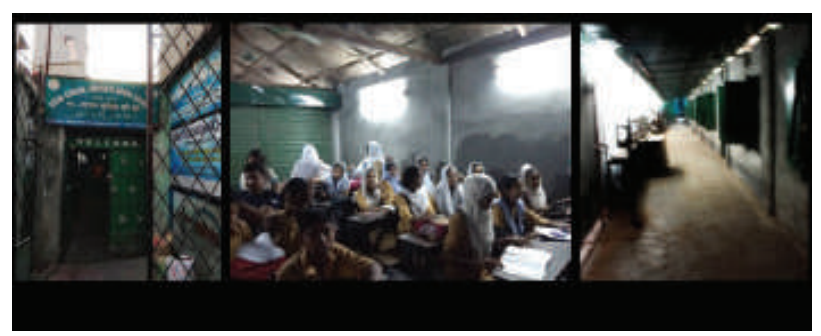

Figure 40: School inside the camp.

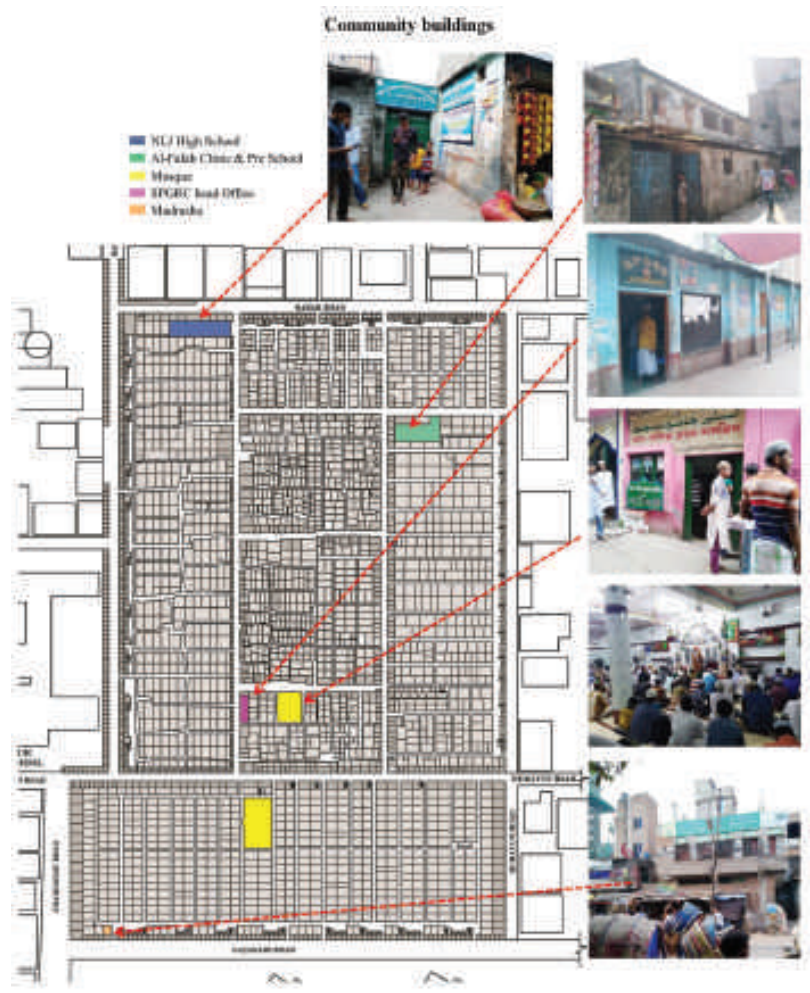

Plate 6: Structures for community functions inside the camp.

\section{Conclusion}

Adequate shelter means more than a roof over one's head. It also means adequate privacy; adequate space; physical accessibility; adequate security; adequate basic 
infrastructure, such as water-supply, sanitation, and waste-management facilities; suitable environmental quality and health-related factors; and adequate and accessible location with regard to work and basic facilities: all of which should be available at an affordable cost.

The camp plays an important role in social categorization of these Urdu speaking people. Geneva camp is not only associated with its past but the location of the camp and socio-economic situation of the camp dwellers also put them in a separate box while comparing with non-camp people. All the camps were highly crowded and the environmental scenario was hazardous. There was inadequate supply of basic facilities like water, electricity and gas. Besides some political and social issues, following are the major problems found by this study need to be addressed to improve the physical living condition of the Geneva camp:

- Living space is too small for a family. Living in a tremendously small space creates many other subsequent problems.

- Drainage and sanitation is in very poor condition. Improper drainage and sanitation is the cause of many diseases and unhealthy living condition.

- Improper waste management is the cause of an unhealthy and unhygienic living environment. The overall camp is like a place with garbage.

- Drinking water is not easy accessible to all of the camp dwellers.

- There is lack of safety and security inside the camp. The narrow and open stairs, open electric line is dangerous for all, especially for kids. The whole camp is in a vulnerable situation in terms of fire hazard.

- Green and open space is not sufficient. For a better living these are necessary.

- Education and Health both are inadequate for the camp dwellers.

\section{Acknowledgement}

Acknowledgement to sixteen under-graduate students of the Architecture Department of Southeast University, Dhaka, Bangladesh. They are- Moukuri Mohim, Md. Arif Hossain, Ambia Akter, Mahmudul Hasan, Umme Sayeda Eva, Fairooz Nawar Rangan, Halima Tamrin, Somayea, Anija Kabir, Nahidur Rahman, Prome Roy Chaity, Md. Mehadi Hasan, Apurba Sarker, Rhain Afroz, Ahmad Tanvir and Md. Khalek Masud.

\section{References}

Abrams, C. (1964). Housing in the Modern World: Man's Struggle for Shelter in an Urbanizing World. Africa Today, 11(8), 12-14.

Bhattacharjee, M. (2018). Dynamics of Social Exclusion in Urban Bangladesh: A Sociological Study of Bihari Community, Bangladesh Sociological Society. Retrieved from bangladeshsociology.org

Haider, Z. (2003). Repatriation of the Biharis Stranded in Bangladesh: Diplomacy and Development. Asian Profile, 31(6), 525-542.

Islam, T., \& Adnan, E.R. (2016). Home within Slum: An Architectural Analysis of Domestic and Community Living in Ershadnagar Resettlement Camp. Bangladesh Planning Research Conference (BPRC).

Iqbal, J., \& Nazneen, S. (2014). Situation Analysis and Recommendations for Water, Sanitation and Hygiene of Mohammadpur Geneva Camp. CUS Bulletin.

Kinyungu, A.N. (2004). Public-Sector Partnerships in the Servicing of Land and Provision of Housing for Low income Groups in Harare: Experiences and Lessons Learnt 1990-1996. RICS Foundation, UK.BBC News. 19 May 2008. Citizenship for Bihari refugees. BBC News. 19 May 2008.

MRGI-Minority Rights Group International (2019). Bihari, World Directory of Minorities and Indigenous Peoples. Retrieved from https://minorityrights.org/ minorities/biharis/ Accessed on 16 September 2019.

Mowla, Q.A., \& Afrin, S. (2008). Evaluating the Housing Situation for the Urban Poor in Dhaka. The Jahangirnagar Review, XXXII, 2008, 91-104.

Muhtasim, A. (2018). Exploring Incremental Modularity of Town Hall Refugee Camp, Context.bd. Retrieved from https://contextbd.com/exploring-incrementalmodularitytown-hall-refugee-camp-aiub/

Rashid, M. (2019). Transformation of Housing in Lowincome Settlement: A Study of Domestic Spaces in Ershad Nagar Resettlement Camp. Nakhara: Journal of Environmental Design and Planning, 16, 119-146.

Refugees International (2006). Citizens of Nowhere: The Stateless Biharis of Bangladesh, report Archived 14 June 2007

Sholder, H. (2011). Housing and Land Rights: The CampDwelling Urdu-Speaking Community in Bangladesh. Refugee and Migratory Movements Research Unit (RMMRU).

Siddiqis, D.M. (2013). Left Behind by The Nation: 'Stranded Pakistanis' in Bangladesh. Sites: new series, 10(1), 150-183.

https://dx.doi.org/10.11157/sites-vol10iss2id253 
The Daily Star (2018). Geneva camp in Dhaka’s Muhammadpur. Retrieved from

https://www.thedailystar.net/city/geneva-campdhakas-muhammadpur-1581955

United Nations High Commission for Refugees (UNHCR) (2000). Chapter 3: Rupture in South Asia. In: The State of The World's Refugees 2000: Fifty Years of Humanitarian Action (pp. 14). Oxford: UNHCR/ Oxford University Press (OUP). Available online at: http://www.unhcr.ch/cgi-bin/texis/opendoc.pdf

UNHCR, (2019). The UN Refugee Agency. Retrieved from https://emergency.unhcr.org/ on 16 September 2019.

United Nations Human Settlements Programme (UNHABITAT), (2003). The Challenge of Slums :
Global Report on Human Settlements. Retrieved from https://www.un.org/ruleoflaw/files/Challenge\%20 of $\% 20$ Slums.pdf

VOA News (2009 October 27). Bangladesh/Pakistan: Bihari Refugees Stranded In Bangladesh Since 1971. Retrieved from https://www.voanews.com/ archive/bangladeshpakistanbihari-refugees-strandedbangladesh-1971

Wikipedia (2019). Stranded Pakistanis in Bangladesh. Retrieved from

https://en.wikipedia.org/wiki/Stranded_Pakistanis_ in_Bangladesh. on 21 September 2019.

\section{旬 CHITKARA}

\section{Creative Space}

Chitkara University, Saraswati Kendra, SCO 160-161, Sector 9-C, Chandigarh, 160009, India

\section{Volume 7, Issue 2}

January 2020

ISSN 2321-3892

Copyright: [C 2020 Masud Ur Rashid] This is an Open Access article published in Creative Space (Creat. Sp.) by Chitkara University Publications. It is published with a Creative Commons Attribution- CC-BY 4.0 International License. This license permits unrestricted use, distribution, and reproduction in any medium, provided the original author and source are credited. 